OPEN ACCESS

ISSN 2548-3501 (online)

Edited by:

Eny Maryanti

Reviewed by:

Supriyati

${ }^{*}$ Correspondence:

Ulpah Halim Ratnawati Tri

Dewi

ulpah.halim@yahoo.com

Received: 22 January 2021

Accepted: 20 June 2021

Published: 31 July 2021

Citation:

Dewi,Sabaruddin, Septemberizal (2021) Antecedent Kepatuhan Pajak Dengan Religiusitas sebagai Pemoderasi

\section{Antecedent Kepatuhan Pajak Dengan Religiusitas sebagai Pemoderasi}

\author{
Ulpah Halim Ratnawati Tri Dewi*, Sabaruddin, Septemberizal \\ Universitas Muhammadiyah Jakarta, Indonesia
}

This study aims to measure and estimate the effect of tax awareness, government policy, image of tax authorities and tax audits on tax compliance with the moderating variable of religiosity. The sample used in this study were 210 individual taxpayers in the Depok, Bekasi, Pondok Gede, Cibinong, Cileungsi, Ciawi and Bogor areas. Quantitative data analysis was performed using WarpPLS 7.0. The results of this study indicate that tax awareness and image of tax authorities have a positive and significant effect on tax compliance, government policies and tax audits have no significant effect on tax compliance, religiosity is able to moderate the effect of tax awareness and tax audits positively and significantly. on tax compliance, but the interaction between religiosity and government policy, as well as the interaction of religiosity with the image of the tax authority does not have a significant effect on tax compliance.

Keywords: tax compliance, tax awareness, image of tax authority, tax audit, religiosity

Penelitian ini bertujuan untuk mengukur dan mengestimasi pengaruh kesadaran pajak, kebijakan pemerintah, citra otoritas pajak dan pemeriksaan pajak terhadap kepatuhan pajak dengan variabel moderasi religiusitas. Sampel yang digunakan dalam penelitian ini yaitu 210 responden wajib pajak orang pribadi di wilayah Depok, Bekasi, Pondok Gede, Cibinong, Cileungsi, Ciawi dan Bogor. Analisis data kuantitatif dilakukan dengan menggunakan WarpPLS 7.0. Hasil penelitian ini menunjukkan bahwa kesadaran pajak dan citra otoritas pajak berpengaruh positif dan signifikan terhadap kepatuhan pajak, kebijakan pemerintah dan pemeriksaan pajak tidak berpengaruh signifikan terhadap kepatuhan pajak, religiusitas mampu memoderasi pengaruh kesadaran pajak dan pemeriksaan pajak secara positif dan signifikan terhadap kepatuhan pajak, namun interaksi antara religiusitas dan kebijakan pemerintah, serta interaksi religiusitas dengan citra otoritas pajak tidak berpengaruh signifikan terhadap kepatuhan pajak.

Keywords: kepatuhan pajak, kesadaran pajak, citra otoritas pajak, pemeriksaan pajak, religiusitas 


\section{PENDAHULUAN}

Kepatuhan pajak merupakan masalah klasik yang dihadapi otoritas pajak di seluruh dunia. Masalah kepatuhan pajak di Indonesia selalu menjadi salah satu poin kebijakan perpajakan untuk menggenjot penerimaan pajak setiap tahunnya. Terlebih lagi pada tahun 2020 ini, DJP harus menghadapi tantangan berat dalam situasi pandemi Covid-19. Meskipun pemerintah telah menurunkan target penerimaan pajak menjadi Rp 1.198,8 triliun, akan tetapi realisasi penerimaan pajak sampai bulan Oktober 2020 ini baru mencapai Rp 830,4 triliun atau setara $69,2 \%$ dari target (portaldjp, diakses 2020).

Selama ini pemerintah masih mengandalkan penerimaan pajak dari sektor PPh badan. Padahal, dari 42 juta NPWP yang tercatat dalam sistem administrasi pajak pada tahun 2019, sebanyak 38,7 juta diantaranya merupakan NPWP orang pribadi. Akan tetapi, penerimaan pajak dari $\mathrm{PPh}$ orang pribadi belum dapat diandalkan, karena tingkat kepatuhannya masih jauh dari harapan. Indikasi ketidakpatuhan wajib pajak orang pribadi terlihat dari tingkat kepatuhan formal dalam menyampaikan SPT Tahunan. Tingkat kepatuhan formal wajib pajak orang pribadi karyawan dan nonkaryawan pada tahun 2018 hanya $71,8 \%$ dan 74,2\%. Selanjutnya, pada tahun 2019 tingkat kepatuhan wajib pajak orang pribadi karyawan dan nonkaryawan sedikit meningkat menjadi $73,2 \%$ dan $75,3 \%$. Pandemi Covid-19 menyebabkan rasio kepatuhan formal wajib pajak orang pribadi per 1 Mei 2020 baru mencapai 65\%, masih ada sekitar 6,3 juta wajib pajak orang pribadi yang belum menyampaikan SPT.

Dengan upaya edukasi, peningkatan kesadaran, dan pengawasan wajib pajak yang optimal, ruang untuk peningkatan kinerja dan kontribusi PPh orang pribadi di masamasa mendatang masih terbuka lebar. Khususnya PPh dari orang pribadi nonkaryawan yang secara penuh menjalankan self assesment system. Cahyonowati dkk. (2012) menjelaskan, dalam rangka meningkatkan kepatuhan perpajakan wajib pajak orang pribadi, otoritas pajak perlu memahami faktor-faktor keperilakuan (behavioral) apa yang mempengaruhi tingkat kepatuhan pajak individu, sehingga dapat menyusun suatu kebijakan yang efektif. Karena wajib pajak orang pribadi merupakan individu yang unik dengan sifat-sifat dasar seperti rasionalitas, memaksimumkan utilitas, dan menghindari risiko.

Berbagai macam faktor menjadi pertimbangan rasionalitas wajib pajak orang pribadi seperti akan taat tehadap aturan pajak jika terdapat kemungkinan besar mereka akan diperiksa dan jika denda pajaknya tinggi. Selain itu, kemungkinan terdapat variabel-variabel lain seperti etika, tingkat kepercayaan terhadap sistem hukum dan perpajakan, serta religiusitas yang mempengaruhi perilaku wajib pajak (Cahyonowati dkk., 2012). Richardson dan Sawyer (2001) mengidentifikasi 14 faktor dalam literatur kepatuhan pajak yang berpotensi berdampak pada kepatuhan wajib pajak. Beragam faktor tersebut mencakup berbagai aspek ekonomi, sosial, budaya dan psikologi yang dapat mempengaruhi perilaku kepatuhan pajak. Faktor-faktor tersebut adalah age, gender, education, income, occupation, other taxpayers influence, ethics, legal sanction, complexity, relationship with taxation authority, income sources, perceived fairness or the tax system, possibility of being audited dan tax rate.

Berdasarkan teori atribusi, sebab perilaku seseorang dalam memenuhi kewajiban perpajakan ditentukan oleh suatu keadaan, baik dari faktor internal maupun eksternal. Ketidakpatuhan wajib pajak orang pribadi yang cukup tinggi merupakan salah satu indikasi masih kurangnya pengetahuan wajib pajak (education). Studi sebelumnya membuktikan bahwa kesadaran pajak berpengaruh signifikan terhadap kepatuhan pajak, diantaranya Saragih dan Desy (2017), Dewi dan Merkusiwati (2018), Putri dan Setiawan (2018), Sukmana dkk. (2018) serta Listyowati dkk. (2018). Yadinta dkk. (2018) mengungkapkan bahwa, wajib pajak orang pribadi sadar untuk patuh membayar pajak terkait dengan persepsi akan fungsi pajak bagi pembiayaan pembangunan, kegunaan pajak dalam penyediaan barang publik, serta keadilan dan kepastian hukum dalam pemenuhan kewajiban perpajakan. Akan tetapi hasil penelitian Palil dkk. (2013) menemukan bahwa tingkat kepatuhan pajak masih rendah, meskipun kesadaran pajak tinggi.

Berbagai literatur mengkaji faktor perceived fairness or the tax system dan complexity sebagai penyebab ketidakpatuhan pajak. Menurut Ratnasari (2019) berbagai program insentif bagi wajib pajak seperti tax amnesty diperlukan untuk memberikan keadilan dalam perpajakan, karena sebagian wajib pajak menganggap peraturan perpajakan sulit dan membebani. Penelitian terkait kebijakan pemerintah dilakukan oleh Dewi dan Merkusiwati (2018) serta Pravasanti (2018), dengan hasil bahwa kebijakan pemerintah seperti program tax amnesty berpengaruh signifikan terhadap kepatuhan wajib pajak orang pribadi. Berbeda dengan Listyowati dkk. (2018), bahwa sunset policy dan tax amnesty tidak mempengaruhi kepatuhan pajak. Kepatuhan wajib pajak orang pribadi hanya bersifat sementara di mana setelah kebijakan sunset policy berakhir, kepatuhan wajib pajak mengalami penurunan. Selain itu, wajib pajak belum tentu akan melaporkan semua hartanya pada saat memanfaatkan program tax amnesty.

Faktor relationship with taxation authority juga dapat mempengaruhi perilaku kepatuhan pajak. Alm dan Torgler (2012) menyatakan bahwa hubungan antara fiskus dengan wajib pajak di negara berkembang seperti hubungan "cops and robbers" karena rendahnya kepercayaan terhadap otoritas pajak. Citra otoritas pajak yang baik dapat meningkatkan kepercayaan dan memotivasi wajib pajak untuk patuh. Hasil penelitian Ratmono dan Cahyonowati (2013) menemukan bahwa meningkatkan kepercayaan masyarakat pada otoritas pajak harus diutamakan karena dapat menumbuhkan kepatuhan sukarela. Oleh karena itu, otoritas pajak perlu menyadari bahwa citranya dapat menjadi rusak karena perilaku otoritas pajak yang melakukan penggelapan pajak, fraud, dan inefisiensi. Citra otoritas pajak yang buruk dapat mendorong wajib pajak yang patuh untuk menjadi tidak patuh. Kiswara dan Jati (2016) juga menyimpulkan bahwa citra otoritas pajak berpengaruh signifikan terhadap kepatuhan wajib pajak orang pribadi. Bertolakbelakang dengan Damayanti dan Martono (2018) yang menyatakan bahwa kepatuhan pajak yang tercipta di Indonesia adalah mandatory compliance, mengingkari self assessment system yang dilandaskan pada voluntary compliance.

Beragam literatur juga membahas faktor deterrence seperti possibility of being audited dapat mempengaruhi kepatuhan pajak. Kirchler dkk. (2008) menyatakan bahwa persepi terhadap kekuatan otoritas pajak seperti adanya pemeriksaan pajak, dapat menimbulkan kepatuhan pajak yang dipaksakan. Beberapa penelitian yang menghubungkan pemeriksaan pajak dengan kepatuhan pajak diantaranya Tagkalakis (2013), Modugu dan Anyaduba (2014), Eliyah dkk. (2016), Sukmawati (2015), Ezer dan Ghozali (2017), Assa dkk. (2018), serta Sukmana dkk. (2018). Hasil penelitian mereka membuktikan bahwa pemeriksaan pajak dapat meningkatkan kepatuhan pajak karena memberikan deterrent effect, sehingga membuat wajib pajak menjadi lebih baik dalam pemenuhan kewajiban perpajakannya. Akan tetapi menurut Cahyonowati dkk. (2012) dan Gangl dkk. (2014), pemeriksaan pajak tidak berpengaruh positif terhadap 
kepatuhan pajak. Pengawasan malah dapat menjadi boomerang, karena intervensi semacam itu dianggap terlalu mengontrol, yang mengurangi penentuan nasib sendiri dan harga diri, sehingga menurunkan motivasi intrinsik untuk patuh.

Masalah ketidakpatuhan pajak juga dapat didalami dari sudut pandang motivasi individual yaitu moralitas (ethics). Halla (2010) serta Alm dan Torgler (2012) pun menyatakan bahwa moral pajak dapat membantu menjelaskan teka-teki mengapa orang mau membayar pajak. Karena ketika seseorang percaya bahwa hukum tersebut sesuai dengan nilai moral mereka, maka mereka akan lebih rela untuk mematuhi hukum (Mahmudah dan Iskandar, 2018). Religiusitas merupakan aspek yang penting dalam moral pajak karena dapat menjadi motivasi untuk membayar pajak, suka rela melaporkan penghasilan, dan peduli dengan sistem perpajakan (Eiya dkk., 2016). Hasil penelitian Palil dkk. (2013) menyatakan bahwa religiusitas merupakan moderator yang signifikan dalam hubungan antara kesadaran pajak terhadap kepatuhan pajak. Religiusitas dapat bertindak sebagai moral internal yang dapat memberikan keyakinan moral dan menjadi motivasi individu untuk sukarela mematuhi pajak (Mahmudah dan Iskandar, 2018).

Variabel moderasi digunakan dalam penelitian ini untuk membuktikan apakah religiusitas seseorang dapat memperkuat atau memperlemah perilaku kepatuhan pajak individu. Berdasarkan beberapa studi sebelumnya, religiusitas dapat mempengaruhi kepatuhan pajak dan dapat mendorong kekuatan moral untuk dapat membedakan yang benar dan salah pada agama apapun (Pope dan Mohdali, 2010). Kepatuhan pajak diharapkan berada pada level yang lebih tinggi, ketika individu berada pada level religiusitas yang tinggi (Muslichah, 2015). Hasil penelitian Sukmana dkk, (2018) menyimpulkan bahwa interaksi religiusitas dengan kesadaran pajak berpengaruh signifikan terhadap kepatuhan pajak. Akan tetapi, Mahmudah dan Iskandar (2018) menyatakan bahwa religiusitas tidak mempengaruhi kepatuhan pajak. Karena kepatuhan pajak dianggap bukan merupakan variabel dari ketaatan beragama. Sehingga nilai-nilai agama tidak memainkan peran penting untuk membuat wajib pajak bertanggung jawab atas kepatuhan pajak.

Berdasar penjelasan di atas dan berbagai penelitian mengenai kepatuhan pajak dengan variabel independen yang berbeda-beda memperlihatkan hasil yang beragam. Inkonsistensi hasil penelitian kepatuhan pajak yang menggunakan religiusitas sebagai variabel moderasi juga menarik untuk dibahas kembali. Oleh karena itu, penulis termotivasi untuk meneliti mengenai kepatuhan pajak, khususnya wajib pajak orang pribadi di Kanwil DJP Jawa Barat III, dengan menggunakan faktor-faktor yang kemungkinan dapat mempengaruhi perilaku kepatuhan pajak individu seperti kesadaran pajak, kebijakan pemerintah, citra otoritas pajak dan pemeriksaan pajak serta religiusitas sebagai pemoderasi.

Tujuan penelitian ini untuk mengukur dan mengestimasi pengaruh kesadaran pajak, kebijakan pemerintah, citra otoritas pajak dan pemeriksaan pajak terhadap kepatuhan pajak. Selain itu, mengukur dan mengestimasi pengaruh kesadaran pajak, kebijakan pemerintah, citra otoritas pajak dan pemeriksaan pajak terhadap kepatuhan pajak yang dimoderasi oleh religiusitas. dengan bentuk penelitian survey. Pengumpulan data melalui kuesioner dengan menggunakan 5 skala Likert. Data dikumpulkan dengan menggunakan instrumen penelitian, analisis data bersifat kuantitatif/statistik dengan tujuan untuk menguji hipotesis yang telah ditetapkan.

\section{Populasi dan Sampel}

Populasi dalam penelitian ini adalah Wajib Pajak orang pribadi yang terdaftar di wilayah Kanwil DJP Jawa Barat III yaitu Bogor, Ciawi, Cibinong, Cileungsi, Depok, Pondok Gede, dan Bekasi sebanyak 465.002. Penghitungan sampel dalam penelitian ini menggunakan rumus Slovin:

$$
n=\frac{N}{N \cdot e^{2}+1}
$$

$$
\begin{aligned}
& \text { Keterangan : } \\
& \mathrm{n}=\text { jumlah sampel } \\
& \mathrm{N}=\text { jumlah populasi } \\
& \mathrm{e}=\text { error (maksimal sebesar } 5 \% \text { ) }
\end{aligned}
$$

Sedangkan pengukuran religiusitas menggunakan Religious Commitment Inventory-10 (RCI-10) dari Worthington dkk. (2003). Dengan margin of error sebesar 5\%, maka diperoleh jumlah sampel yang akan digunakan dalam penelitian ini yaitu 400 responden.

$$
\begin{aligned}
& n=\frac{465.002}{465.002(0,05)^{2}+1} \\
& n=400
\end{aligned}
$$

\section{Metode Analisis Data}

Teknik analisis yang digunakan untuk menguji hipotesis dalam penelitian ini adalah dengan melihat path coefficients yang menunjukkan koefisien parameter dan nilai signifikansi $\mathrm{t}$ statistik. Pengujian validitas dan reliabilitas dilakukan dengan melihat nilai Loading Factor, Cronbach's Alpha dan Composite Reliability. Sedangkan analisis inner model dengan melihat Model Fit dan Quality Indices. Peneliti menggunakan WarpPLS versi 7.0 untuk menganalisis data yang dikumpulkan dengan tahapan merancang Inner Model, merancang Outer Model, mengkonstruksi diagram jalur, konversi diagram jalur ke sistem persamaan, estimasi outer model dan inner model, evaluasi Goodness of Fit, dan pengujian hipotesis (Resampling Bootstraping).

\section{HASIL DAN PEMBAHASAN}

Peneliti menyebarkan 259 kuesioner melalui googleform dan 141 kuesioner hardcopy. Wajib pajak yang mengisi kuesioner melalui googleform sebanyak 98 orang, sedangkan yang mengisi kuesioner hardcopy sebanyak 112 orang. Sehingga jumlah kuesioner yang dapat diolah dan dijadikan sumber data adalah 210 kuesioner. Penyebaran kuesioner dan partisipasi responden dalam mengisi dan mengembalikan kuesioner dapat dilihat dalam tabel 1 berikut ini.

\section{METODE}

\section{Jenis Penelitian}

Jenis penelitian yang digunakan adalah penelitian kuantitatif 


\section{Latar Belakang Responden}

Latar belakang responden dalam penelitian ini yaitu $60 \%$ responden adalah laki-laki, lebih banyak berusia antara 36-50 tahun $(40 \%)$ dan beragama Islam (84\%). Sebagian besar responden merupakan karyawan dengan pendidikan formal $51,5 \%$ adalah perguruan tinggi $(\mathrm{S} 1)$, namun $77,6 \%$ responden tidak mengikuti program tax amnesty.

[Table 1 about here.]

\section{Validitas Konvergen}

Nilai outer model atau korelasi antar konstruk setiap variabel yaitu $\mathrm{X}_{1}, \mathrm{X}_{2}, \mathrm{X}_{3}, \mathrm{X}_{4}, \mathrm{Y}$ dan $\mathrm{Z}$ menunjukkan bahwa semua combined loading dan cross loading telah sesuai dengan kriteria yang telah ditetapkan, memiliki nilai diatas 0,50 . Semua faktor menunjukkan signifikan $p$-value $<0,001$. Sehingga dapat disimpulkan bahwa setiap pengukuran variabel dikatakan valid dan signifikan terhadap konstruknya.

\section{Validitas Diskriminan}

Uji validitas diskriminan berhubungan dengan prinsip bahwa pengukur-pengukur konstruk yang berbeda seharusnya tidak berkolerasi tinggi, dengan melihat nilai cross loading untuk setiap variabel. Jika square root of average variance extracted $(\mathrm{AVE})>0,5$ maka dikatakan memiliki validitas diskriminan yang baik. Berdasarkan tabel 2 di bawah ini, hasil pengujian validitas diskriminan setiap variabel menunjukkan valid

\section{[Table 2 about here.]}

\section{Uji Reliabilitas}

Berdasarkan tabel 3 berikut, dapat disimpulkan bahwa masingmasing konstruk memiliki composite reliability coefficient untuk variabel $X_{1}, X_{2}, X_{3}, X_{4}, Y$ dan $Z$ telah memenuhi standar yang telah ditetapkan yakni $>0,7$ atau dapat dikatakan reliabilitas dapat diterima (cukup baik). Selanjutnya dapat dilihat juga bahwa setiap konstruk memiliki cronbach's alpha coefficients untuk variabel $\mathrm{X}_{1}, \mathrm{X}_{2}, \mathrm{X}_{3}, \mathrm{X}_{4}, \mathrm{Y}$ dan $\mathrm{Z}$ juga memenuhi standar yang telah ditetapkan yakni $>0,6$ atau dapat dikatakan reliabilitas cukup dan dapat diterima.

[Table 3 about here.]

\section{Pengujian Inner Model}

Sebelum dilakukan interpretasi terhadap hasil pengujian hipotesis, model seharusnya memiliki Goodness of Fit, yaitu indeks dan ukuran kebaikan hubungan antar variabel laten yang baik. Hasil analisis WarpPLS 7.0 untuk model fit and quality indices dalam penelitian ini disajikan dalam tabel 4 berikut ini.

[Table 4 about here.]

\section{Pengujian Koefisien Korelasi dan Koefisien Determinan}

\author{
[Table 5 about here.]
}

Nilai koefisien korelasi (R-square) variabel kepatuhanpajak sebesar 0,483 dengan nilai koefisien determinasi (adjusted R-square) sebesar 0,462. Artinya bahwa variabel konstruk kepatuhan pajak dapat dijelaskan oleh variabel konstruk kesadaran pajak $\left(\mathrm{X}_{1}\right)$, kebijakan pemerintah $\left(\mathrm{X}_{2}\right)$, citra otoritas pajak $\left(\mathrm{X}_{3}\right)$ dan pemeriksaan pajak $\left(\mathrm{X}_{4}\right)$ dengan moderasi religiusitas sebesar 48,3\%. Sedangkan sisanya yaitu sebesar $51,7 \%$ dijelaskan oleh variabel lain di luar penelitian ini.

\section{Pengujian Hipotesis}

[Figure 1 about here.]

[Table 6 about here.]

Dalam penelitian ini dikembangkan delapan hipotesis yang berusaha menjelaskan hubungan antara variabelvariabel dan pengkajian interaksinya dengan religiusitas terhadap kepatuhan pajak. Pengujian hipotesis yang diajukan dilakukan dengan melihat path coefficients yang menunjukkan koefisien parameter dan nilai signifikansi $\mathrm{t}$ statistik. Suatu hipotesis dapat diterima atau harus ditolak secara statistik dapat dihitung melalui tingkat signifikansinya. Pengujian dilakukan dengan t-test, bilamana diperoleh $p$-value $\leq 0,10$ (alpha 10\%) maka dikatakan weakly significant, jika p-value $\leq 0,05$ (alpha $5 \%$ ) dikatakan significant dan jika $p$-value $\leq 0,01$ (alpha $1 \%$ ) maka dikatakan highly significant. Dasar pengambilan keputusan berdasarkan nilai signifikansinya yaitu jika nilai probabilitas $(p$-values $)<0,05$ maka hipotesis diterima (ada pengaruh signifikan). Jika nilai Probabilitas $(P$-values $)>0,05$ maka hipotesis ditolak (pengaruh tidak signifikan).

Sedangkan variabel moderasi diklasifikasikan menjadi 5 jenis yaitu moderasi mutlak (absolute moderation), moderasi murni (pure moderation), moderasi semu (quasi moderation), moderasi potensial (homologiser moderation) dan moderasi sebagai penjelas (predictor moderation). Berdasarkan tabel 6 di atas terlihat bahwa :Kesadaran pajak berpengaruh signifikan terhadap kepatuhan pajak. Dapat dilihat dari nilai $p$-value $<0.05$ $(0.001<0.05)$, sehingga hipotesis terbukti dan diterima. Kebijakan pemerintah berpengaruh tidak signifikan terhadap kepatuhan pajak. Hal tersebut terlihat dari nilai p-value $>0.05(0.328>0.05)$, sehingga hipotesis tidak terbukti. Citra otoritas pajak berpengaruh signifikan terhadap kepatuhan pajak. Dapat dilihat dari nilai $p$-value $<0.05(0.05<0.05)$, sehingga hipotesis terbukti dan diterima. Pemeriksaan pajak berpengaruh tidak signifikan terhadap kepatuhan pajak. Hal tersebut terlihat dari nilai $\mathrm{p}$-value $>0.05(0.062>0.05)$, sehingga hipotesis tidak terbukti. Religiusitas signifikan memoderasi pengaruh kesadaran pajak terhadap kepatuhan pajak. Hal itu dapat dilihat dari nilai $p$-value $<0.05(0.01<0.05)$, sehingga hipotesis terbukti dan diterima. Religiusitas tidak signifikan memoderasi pengaruh kebijakan pemerintah terhadap kepatuhan pajak. Terlihat dari nilai nilai p-value $>0.05(0.395>0.05)$, sehingga hipotesis tidak terbukti. Religiusitas tidak signifikan memoderasi pengaruh citra otoritas pajak terhadap kepatuhan pajak. Hal itu dapat dilihat dari nilai p-value > 0.05 (0.183> 0.05), sehingga hipotesis tidak terbukti. Religiusitas signifikan memoderasi pengaruh pemeriksaan pajak terhadap kepatuhan pajak. Dapat dilihat dari nilai $p$-value $<0.05(0.001<0.05)$, sehingga hipotesis terbukti dan diterima. 


\section{Pembahasan}

\section{Pengaruh Kesadaran Pajak Terhadap Kepatuhan Pajak}

Hasil penelitian menemukan bahwa kesadaran pajak berpengaruh signifikan terhadap kepatuhan pajak. Hal ini dapat dilihat pada tabel 6 di atas, dimana nilai p-values $<0,05(0,001$ $<0,05)$, sehingga hipotesis diterima. Nilai koefisien path $(\beta)$ sebesar 0,624 artinya memiliki pengaruh positif signifikan dimana jika kesadaran pajak naik maka kepatuhan pajak juga
akan naik sebesar 0,624 . Hasil penelitian ini sesuai dengan teori atribusi, bahwa perilaku kepatuhan pajak disebabkan adanya pengaruh internal seseorang. Faktor internal tersebut seperti sifat, karakter, sikap, kemampuan seseorang yang dapat mempengaruhi kesadaran wajib pajak.

Hasil penelitian ini juga memperkuat hasil penelitian terdahulu diantaranya Saragih dan Desy (2017), Dewi dan Merkusiwati (2018), Putri dan Setiawan (2018), Sukmana dkk. (2018) Yadinta dkk. (2018) serta Listyowati dkk. (2018) yang menemukan bahwa kesadaran pajak berpengaruh signifikan terhadap kepatuhan wajib pajak orang pribadi.

\section{Pengaruh Kebijakan Pemerintah Terhadap Kepatuhan Pajak}

Berdasarkan hasil penelitian ini, kebijakan pemerintah tidak berpengaruh terhadap kepatuhan pajak. Tabel 6 menunjukkan bahwa nilai p-values > dari $0,05(0,328>0,05)$, sehingga hipotesis ditolak. Nilai koefisien path $(\beta)$ sebesar 0,031 artinya memiliki pengaruh positif (weakly significant), yaitu jika kebijakan pemerintah meningkat maka kepatuhan pajak hanya akan meningkat sebesar 0,031. Hasil penelitian ini tidak mendukung teori atribusi, adanya pengaruh eksternal seperti kebijakan pemerintah yang baik dan adil, dapat mempengaruhi perilaku kepatuhan individu. Bertentangan juga dengan teori pembelajaran sosial, bahwa kebijakan pemerintah yang memudahkan dan menguntungkan wajib pajak dapat mempengaruhi perilaku serta memotivasi wajib pajak untuk patuh.

Penelitian ini berlawanan hasil dengan penelitian Dewi dan Merkusiwati (2018) serta Pravasanti (2018), bahwa kebijakan pemerintah seperti program tax amnesty berpengaruh signifikan terhadap kepatuhan wajib pajak orang pribadi. Serta tidak sejalan dengan Ratnasari (2019) yang menyatakan bahwa berbagai program insentif bagi wajib pajak seperti tax amnesty diperlukan untuk memberikan keadilan dalam perpajakan, karena sebagian wajib pajak menganggap peraturan perpajakan sulit dan membebani.

Pengaruh Citra Otoritas Pajak Terhadap Kepatuhan Pajak Menurut penelitian ini, citra otoritas pajak berpengaruh signifikan terhadap kepatuhan pajak. Tabel 6 memperlihatkan nilai $\mathrm{p}$-values $<$ dari $0,05(0,05<0,05)$, sehingga hipotesis diterima. Nilai koefisien path $(\beta)$ sebesar 0,108 artinya memiliki pengaruh positif, dimana jika citra otoritas pajak meningkat, maka kepatuhan pajak juga akan meningkat sebesar 0,108. Hasil penelitian ini mendukung teori atribusi, perilaku kepatuhan pajak individu dapat disebabkan oleh faktor eksternal seperti citra otoritas pajak yang baik/tidak. Sejalan juga dengan teori pembelajaran sosial yang menyatakan bahwa seseorang akan patuh membayar kewajiban perpajakannya tepat waktu, jika mereka yakin (berdasarkan pengamatan dan pengalaman), bahwa pemerintah yang memungut pajak memberikan kontribusi yang besar bagi pembangunan daerahnya.
Penelitian ini juga memperkuat pendapat Kirchler dkk. (2008), bahwa citra otoritas pajak yang baik akan mendorong kepercayaan wajib pajak dan akan meningkatkan kepatuhan sukarela. Serta sejalan dengan hasil penelitian Amriani dkk. (2014), Ratmono (2014), Kiswara dan Jati (2016), serta Prichard dkk. (2019) yang menyimpulkan bahwa citra otoritas pajak berpengaruh signifikan terhadap kepatuhan wajib pajak orang pribadi. Timbulnya sikap wajib pajak yang selalu taat membayar dan melaporkan pajak tepat waktu karena adanya kepercayaan pada otoritas pajak.

Pengaruh Pemeriksaan Pajak Terhadap Kepatuhan Pajak Hasil penelitian ini menemukan bahwa pemeriksaan pajak tidak berpengaruh terhadap kepatuhan pajak. Terlihat dari tabel 6 di atas, nilai $\mathrm{p}$-values $>$ dari $0,05(0,062>0,05)$, sehingga hipotesis ditolak. Nilai koefisien path $(\beta)$ sebesar 0,105 artinya memiliki pengaruh positif (weakly significant), yaitu jika pemeriksaan pajak meningkat maka kepatuhan pajak juga akan meningkat sebesar 0,105. Hasil penelitian ini tidak sejalan dengan teori atribusi, bahwa adanya pemeriksaan pajak apabila tidak patuh merupakan faktor eksternal yang dapat mempengaruhi perilaku kepatuhan individu. Bertentangan juga dengan teori pembelajaran sosial, yang menyatakan bahwa apabila individu diberikan punishment seperti pemeriksaan pajak, maka mereka akan berperilaku sesuai model, yaitu patuh pajak. Tidak mendukung pendapat.

Menurut Kirchler dkk. (2008), persepi terhadap kekuatan otoritas pajak seperti adanya pemeriksaan pajak, dapat menimbulkan kepatuhan pajak yang dipaksakan. Hasil penelitian ini tidak mendukung dan tidak memperkuat beberapa hasil penelitian yang menghubungkan pemeriksaan pajak dengan kepatuhan pajak diantaranya Tagkalakis (2013), Modugu dan Anyaduba (2014), Eliyah dkk. (2016), Sukmawati (2015), Ezer dan Ghozali (2017), Assa dkk. (2018), serta Sukmana dkk. (2018). Karena hasil penelitian mereka membuktikan bahwa pemeriksaan pajak dapat meningkatkan kepatuhan pajak karena memberikan deterrent effect, sehingga membuat wajib pajak menjadi lebih baik dalam pemenuhan kewajiban perpajakannya.

\section{Pengaruh Kesadaran Pajak Terhadap Kepatuhan Pajak} dengan Moderasi Religiusita

Berdasarkan hasil penelitian, terlihat bahwa interaksi kesadaran pajak dan religiusitas berpengaruh signifikan terhadap terhadap kepatuhan pajak. Dalam tabel 6 terlihat nilai p-values < dari $0,05(0,01<0,05)$, sehingga hipotesis diterima. Nilai koefisien path $(\beta)$ sebesar 0,158 , dengan keterangan Quasi moderation yang artinya moderasi semu ( $\mathrm{X}_{1}$ signifikan, $\mathrm{X}_{1} * \mathrm{Z}$ signifikan). Hasil penelitian ini sejalan dengan teori atribusi yang menyatakan bahwa perilaku kepatuhan pajak dapat disebabkan adanya pengaruh internal seseorang seperti sifat, karakter, sikap, dan kemampuan. McKerchar dkk. (2013) menyimpulkan bahwa integritas pribadi memiliki pengaruh yang besar kenapa mereka melaporkan dan membayar pajak dengan jujur. Hasil penelitian ini memperkuat penelitian Palil dkk. (2013) yang menyatakan bahwa religiusitas merupakan moderator yang signifikan dalam hubungan antara kesadaran pajak terhadap kepatuhan pajak. Religiusitas dapat bertindak sebagai moral internal yang dapat memberikan keyakinan moral dan menjadi motivasi individu untuk sukarela mematuhi pajak (Mahmudah dan Iskandar, 2018). Alm dan Torgler (2012) juga menyebutkan bahwa etika masing-masing individu dapat mempengaruhi keputusan kepatuhan pajak.

Pengaruh Kebijakan Pemerintah
Pajak dengan Moderasi Religiusitas 
Penelitian ini menjelaskan bahwa interaksi antara kebijakan yang menemukan bahwa moral pajak dapat membantu pemerintah dengan religiusitas tidak berpengaruh terhadap menjelaskan teka-teki mengapa orang membayar pajak, kepatuhan pajak. Hal ini dapat dilihat dari tabel 6 yang meskipun terdapat probabilitas audit dan tarif denda yang memperlihatkan nilai p-values > dari 0,05 (0,395 > 0,05), rendah. Religiusitas dapat mempengaruhi perilaku tertentu, sehingga hipotesis ditolak. Nilai koefisien path $(\beta)$ sebesar seperti perilaku curang. Karena religiusitas merupakan dasar 0,018, dengan keterangan Homologiser moderation yang artinya penting untuk menghindari bentuk perilaku yang menyimpang moderasi potensial ( $\mathrm{X}_{2}$ tidak signifikan, $\mathrm{X}_{2} * \mathrm{Z}$ tidak signifikan). seperti penghindaran pajak (Mahmudah dan Iskandar, 2019).

Hasil penelitian ini tidak sejalan dengan teori atribusi bahwa perilaku kepatuhan pajak dapat dipengaruhi oleh faktor internal seperti religiusitas. Meskipun banyak penelitian yang berfokus pada hubungan antara agama dan perilaku telah menegaskan bahwa agama sangat mempengaruhi pengalaman emosional, pemikiran, perilaku, dan kesejahteraan psikologis seseorang (Muclishah, 2015).

Pada hasil penelitian ini peran agama tidak mempengaruhi keyakinan dan perilaku seseorang terhadap kebijakan yang dikeluarkan oleh pemerintah terkait pajak, dikarenakan tujuan dari kebijakan pemerintah berbeda dengan konsep religiusilitas. Memperkuat hasil penelitan Sukmana dkk. (2018) bahwa seseorang bukan tidak mampu untuk membayar pajak, namun konsep perpajakan tersebut bertentangan dengan keyakinan agama yang dianutnya. Sehingga religiusitas seseorang tidak mampu memoderasi pengaruh kebijakan pemerintah terhadap kepatuhan pajak.

Pengaruh Citra Otoritas Pajak Terhadap Kepatuhan Pajak dengan Moderasi Religiusitas

Penelitian ini menemukan bahwa interaksi citra otoritas pajak dengan religiusitas tidak mempengaruhi kepatuhan pajak. Dari tabel 6 dapat dilihat nilai p-values > dari $0,05(0,183>0,05)$, sehingga hipotesis ditolak. Nilai koefisien path $(\beta)$ sebesar 0,062 , dengan keterangan Predator moderation yang artinya moderasi penjelas ( $\mathrm{X}_{3}$ signifikan, $\mathrm{X}_{3} * \mathrm{Z}$ tidak signifikan). Hasil penelitian ini tidak sejalan dengan teori atribusi dan juga tidak mendukung teori pembelajaran sosial, dimana seorang wajib pajak dapat mempertimbangkan pengalamannya seperti jenis pemerintahan (termasuk otoritas pajak) dan sifat masyarakat (termasuk pengaruh rekan kerja) selama proses pengambilan keputusan kepatuhan pajak. Pada saat yang sama, dia dapat menggunakan elemen internal seperti keyakinan religius untuk memutuskan apakah akan mematuhi atau tidak

Hasil penelitian ini menunjukkan bahwa konsep religiusitas tidak mampu memperkuat atau memperlemah pengaruh citra otoritas pajak terhadap kepatuhan pajak seseorang, karena pajak masih menjadi tanda tanya besar jika dihubungkan dengan agama. Hal tersebut berlawanan dengan penelitian Pope dan Mohdali (2010), bahwa ketika wajib pajak menerima layanan publik sebagai imbalan atas pajak yang mereka bayarkan, akan mempengaruhi moral pajak, sehingga wajib pajak cenderung untuk mematuhi undang-undang perpajakan.

Pengaruh Pemeriksaan Pajak Terhadap Kepatuhan Pajak dengan Moderasi Religiusitas

Hasil penelitian ini membuktikan bahwa interaksi pemeriksaan pajak dan religiusitas berpengaruh signifikan terhadap terhadap kepatuhan pajak. Terbukti dalam tabel 6 di atas, nilai p-values $<$ dari $0,05(0,001<0,05)$, sehingga hipotesis diterima. Nilai koefisien path $(\beta)$ sebesar 0,214 , dengan keterangan Pure moderation yang artinya moderasi murni ( $\mathrm{X}_{4}$ tidak signifikan, $\mathrm{X}_{4} * \mathrm{Z}$ signifikan). Hasil penelitian ini mendukung teori atribusi, bahwa faktor internal seperti religiusitas dapat mempengaruhi perilaku kepatuhan pajak. Sedangkan menurut Palil dkk. (2013), nilai-nilai agama memainkan peran yang sangat penting untuk membuat wajib pajak bertanggung jawab atas kepatuhan pajak.

Hasil penelitian ini juga memperkuat penelitian Halla (2010)

\section{KESIMPULAN}

Berdasarkan penjelasan di atas, maka penelitian ini dapat ditarik kesimpulan sebagai berikut :

'Kesadaran pajak berpengaruh positif dan signifikan terhadap kepatuhan pajak, semakin tinggi kesadaran pajak, maka akan berdampak pada tingginya kepatuhan pajak. Faktor internal seperti sifat, karakter, sikap, kemampuan seseorang dapat mempengaruhi kesadaran wajib pajak. Apabila seseorang memiliki keyakinan mengenai pentingnya membayar pajak untuk membantu menjaga keberlangsungan negara, maka akan timbul niat untuk sadar pajak. Kesadaran pajak tersebut akan membentuk sikap/perilaku patuh pajak.

Kebijakan pemerintah tidak berpengaruh signifikan terhadap kepatuhan pajak. Tingginya kepatuhan pajak ternyata tidak dipengaruhi oleh kebijakan pemerintah, meskipun terdapat beberapa program pemerintah yang baik, dibandingkan dengan program pemerintah yang buruk lainnya, yang sering ditandai dengan fraud dan inefisiensi.

Citra otoritas pajak berpengaruh positif dan signifikan terhadap kepatuhan pajak. Citra otoritas pajak yang baik dapat meningkatkan kepercayaan dan memotivasi wajib pajak untuk patuh. Timbulnya sikap wajib pajak yang selalu taat membayar dan melaporkan pajak tepat waktu karena adanya kepercayaan pada otoritas pajak.

Pemeriksaan pajak tidak berpengaruh signifikan terhadap kepatuhan pajak. Tingginya kepatuhan pajak ternyata tidak dipengaruhi oleh adanya pemeriksaan pajak. Karena individu yang diberikan punishment seperti pemeriksaan pajak, ternyata tidak membuat mereka akan berperilaku sesuai model, yaitu patuh pajak. Bahkan persepsi terhadap kekuatan otoritas pajak seperti adanya pemeriksaan pajak, hanya akan menimbulkan kepatuhan pajak yang dipaksakan.

Interaksi hubungan kesadaran pajak dan religiusitas berpengaruh positif dan signifikan terhadap kepatuhan pajak. Karena religiusitas dapat bertindak sebagai moral internal yang dapat memberikan keyakinan moral dan menjadi motivasi individu untuk sukarela mematuhi pajak. Selain itu, etika masingmasing individu dapat mempengaruhi keputusan kepatuhan pajak.

Interaksi hubungan kebijakan pemerintah dan religiusitas tidak berpengaruh signifikan terhadap kepatuhan pajak. Peran agama tidak mempengaruhi keyakinan dan perilaku seseorang terhadap kebijakan yang dikeluarkan oleh pemerintah terkait pajak, dikarenakan tujuan dari kebijakan pemerintah berbeda dengan konsep religiusilitas.

Interaksi hubungan citra otoritas pajak dan religiusitas berpengaruh negatif dan tidak signifikan terhadap kepatuhan pajak. Konsep religiusitas tidak mampu memperkuat atau memperlemah pengaruh citra otoritas pajak terhadap kepatuhan pajak seseorang, karena pajak masih menjadi tanda tanya besar jika dihubungkan dengan agama.

Interaksi hubungan pemeriksaan pajak dan religiusitas berpengaruh positif dan signifikan terhadap kepatuhan pajak. Moral pajak dapat membantu menjelaskan teka-teki mengapa orang membayar pajak, meskipun terdapat probabilitas audit 
dan tarif denda yang rendah. Religiusitas dapat mempengaruhi perilaku tertentu, seperti perilaku curang. Karena religiusitas merupakan dasar penting untuk menghindari bentuk perilaku yang menyimpang seperti penghindaran pajak.

\section{REFERENCES}

Alm, J. Dan B. Torgler. (2012). Do Ethics Matter? Tax Compliance and Morality. Tulane Economics Working Paper Series. Working Paper 1207 July 2012.

Amriani dkk. (2014) Pengaruh Kepercayaan dan Kekuasaan Dalam Otoritas Pemerintah Terhadap Kepatuhan Pajak. ejurnal.bunghatta.ac.id. Vol 4 No 1 (2014).

Assa dkk. (2018). Pengaruh Pemeriksaan Pajak dan Sanksi Perpajakan Terhadap Kepatuhan Wajib Pajak Pada KPP Pratama Manado. Jurnal Riset Akuntansi Going Concern 13(4), 2018, 516-522.

Cahyonowati dkk. (2012). Peranan Etika, Pemeriksaan, Dan Denda Pajak Untuk Meningkatkan Kepatuhan Wajib Pajak Orang Pribadi. Jurnal Akuntansi dan Keuangan Indonesia Volume 9 Nomor 2, Desember 2012.

Dewi, L.P.S.K. dan N. K. Merkusiwati. (2018). Pengaruh Kesadaran Wajib Pajak, Sanksi Perpajakan, E-Filing, dan Tax Amnesty Terhadap Kepatuhan Pelaporan Wajib Pajak. E-Jurnal Akuntansi Universitas Udayana Vol.22.2. Februari (2018): 1626-1655.

Eiya dkk. (2016). Religiosity And Tax Compliance: Empirical Evidence From Nigeria. Igbinedion University Journal of Accounting. Vol. 1 February, 2016.

Eliyah dkk. (2016). Penerapan Self Assessment, Pengetahuan Wajib Pajak, Pemeriksaan Pajak Pada Kepatuhan Wajib Pajak. Jurnal Riset Akuntansi dan Perpajakan Vol. 3, No. 1, Juni 2016, hal 95-108 ISSN 2339 - 1545.

Ezer, E. dan Ghozali. (2017). Pengaruh Tingkat Pendapatan, Tarif Pajak, Denda Pajak, Dan Probabilitas Pemeriksaan Pajak Terhadap Kepatuhan Pajak. Diponegoro Journal Of Accounting. Volume 6, Nomor 3, Tahun 2017, Halaman 1-13. ISSN (Online): 2337-3806.

Gangl, K dkk. (2014). Effects of supervision on tax compliance: Evidence from a field experiment in Austria. Economics Letters 123 (2014) 378-382.

Halla, M. (2010). Tax Morale and Compliance Behavior: First Evidence on a Causal Link. University of Linz and IZA. Discussion Paper No. 4918, April 2010.

Kamil, N. Islamiah. (2015). The Effect of Taxpayer Awareness, Knowledge, Tax Penalties and Tax Authorities Services on the Tax Complience: (Survey on the Individual Taxpayer at Jabodetabek \& Bandung). Research Journal of Finance and Accounting. www.iiste.org ISSN 2222-1697 Vol.6, No.2, 2015.

Kirchler dkk. (2008). Enforced Versus Voluntary Tax Compliance: The "Slippery Slope" Framework. Journal of Economic Psychology 29 (2008) 210-225.

Kiswara, D dan I.K. Jati. (2016). Pengaruh Penerapan E-filing, dan Peran Account Representative Terhadap Pencitraan Otoritas Pajak dan Kepatuhan Wajib Pajak. E-Jurnal Akuntansi Universitas Udayana. Vol.15.1 April (2016): 249-377.

Listyowati dkk. (2018). Faktor-Faktor Yang Mempengaruhi Kepatuhan Wajib Pajak Dalam Membayar Pajak. Jurnal Riset Akuntansi dan Bisnis Airlangga Vol. 3. No. 1 (2018) 372-395 ISSN 2548-1401 (Print) ISSN 25484346.

Luttmer, Erzo F.P. and Monica Singhal. (2014). Tax Morale. Journal of Economic Perspectives Volume 28, Number 4
Fall 2014, Pages 149-168.

Mahmudah, M dan D.D. Iskandar. (2018). Analisis Dampak Tax Morale Terhadap Kepatuhan Pajak UMKM: Studi Kasus Kota Semarang. www.researchgate.net. April 2018 .

Mckerchar dkk. (2013). Indicators of Tax Morale: An Exploratory Study. eJournal of Tax Research (2013) vol. 11 , no. 1 , pp. 5-22.

Modugu, K.P. dan John O. Anyaduba. (2014). Impact of Tax Audit on Tax Compliance in Nigeria. International Journal of Business and Social Science Vol. 5, No. 9; August 2014.

Muslichah. (2015). The Effect of Tax Simplication on Taxpayer's Compliance Behavior: Religosity as Moderating Variable. Jurnal Keuangan dan Perbankan, Vol.19, No.1 Januari 2015, hlm. 98-108.

Palil, M. Rizal dan A.F. Mustapha. (2011). Factors Affecting Tax Compliance Behaviour In Self Assessment System. African Journal of Business Managemen Vol. 5(33), pp. 12864-12872, 21 December, 2011.

Palil dkk. (2013). The Perception of Tax Payers on Tax Knowledge and Tax Education with Level of Tax Compliance: A Study the Influences of Religiosity. ASEAN Journal of Economics, Management and Accounting 1 (1): 118-129 (June 2013) ISSN 2338-9710.

Pope, J. dan R. Mohdali. (2010). The Role Of Religiosity In Tax Morale And Tax Compliance. Australian Tax Forum. Januari 2011.

Pravasanti, Y.A. (2018). Dampak Kebijakan dan Keberhasilan Tax Amnesty Bagi Perekonomian Indonesia. Jurnak Ilmiah Akuntansi XVI(1), Maret 2018: 84-94.

Prichard dkk. (2019). Innovations in Tax Compliance : Conceptual Framework. Policy Research Working Paper 9032.

Putri, J. dan E. Setiawan. (2017). Pengaruh Kesadaran, Pengetahuan dan Pemahaman Perpajakan, Kualitas Pelayanan dan Sanksi Perpajakan Terhadap Kepatuhan Wajib Pajak. E-Jurnal Akuntansi Universitas Udayana. Vol.18.2. Februari (2017): 1112-1140.

Ratmono, D. dan N. Cahyonowati. (2013). Kepercayaan Terhadap Otoritas Pajak Sebagai Pemoderasi Pengaruh Deterrence Factors Terhadap Kepatuhan Wajib Pajak Pribadi. Jurnal Akuntansi Indonesia, Vol. 2 No. 1 Januari 2013, Hal. 1-15.

Ratmono, D. (2014). Model Kepatuhan Perpajakan Sukarela: Peran Denda, Keadilan Prosedural, dan Kepercayaan Terhadap Otoritas Pajak. JAAI Volume 18 No.1, Juni 2014: 42-64.

Ratnasari, M. (2019). Kepatuhan Pajak Program Insentif Tax Amnesty : Sebuah Pendekatan Mixed Methods Dan Bukti Empiris Pada Wajib Pajak (WP). Ultima Accounting Vol. 11 No. 1 ISSN 2085-4595.

Richardson, M dan A.J. Sawyer. (2001). A Taxonomy of the Tax Compliance Literature: Further Findings, Problems and Prospects. (2001) 16 Australian Tax Forum.

Saragih, F dan Desy S. (2017). Pengaruh Kesadaran Wajib Pajak, Pemahaman Peraturan Perpajakan Dan Sanksi Pajak Terhadap Kepatuhan Wajib Pajak Orang Pribadi. Jurnal Manajemen Perpajakan Volume 6 Nomor 1.

Sukmana dkk. (2018). Studi Kesadaran Pajak Terhadap Kepatuhan Pajak dan Religiusitas Sebagai Pemoderasi. Jurnal Ekonomi Bisnis Dan Manajemen. Vol 3 No 1 (2018).

Sukmawati, R. (2015). Pengaruh Pelayanan, Pengawasan dan Konsultasi Yang Dilaksanakan Oleh Account Representative Serta Pemeriksaan Pajak Terhadap 
Kepatuhan Wajib Pajak Badan Yang Terdaftar di KPP Madya Pekanbaru. Jom. Fekon Vol. 2 No. 2 Oktober 2015.

Tagkalakis, A.O. (2013). Audits And Tax Offenders: Recent Evidence From Greece. Working Paper Bank Of Greece. Economic Research Department - Special Studies Division. ISSN 1109-6691.

Yadinta dkk. (2018). Kualitas Pelayanan Fiskus, Dimensi Keadilan, Kesadaran Wajib Pajak dan Kepatuhan Wajib Pajak Orang Pribadi. Jurnal Riset Akuntansi dan Perpajakan JRAP Vol. 5, No. 2, Desember 2018, hal 201212.

Worthington dkk. (2003). The Religious Commitment Inventory-10: Development, Refinement, and Validation of a Brief Scale for Research and Counseling. Journal of Counseling Psychology, 50(1):84- 96.

Copyright (c) 2020 and. This is an open-access article distributed under the terms of the Creative Commons Attribution License (CC BY). The use, distribution or reproduction in other forums is permitted, provided the original author(s) and the copy-right owner(s) are credited and that the original publication in this journal is cited, in accordance with accepted academic practice. No use, distribution or reproduction is permitted which does not comply with these terms. 


\section{LIST OF TABLES}

1 Tingkat Pengembalian Kuesioner Responden Berdasarkan Usia Responden Berdasarkan Tingkat Pendidikan, Agama dan Mengikuti Tax Amnesty ............................................................................................................... 151

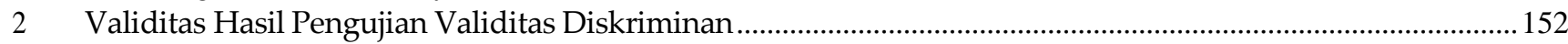

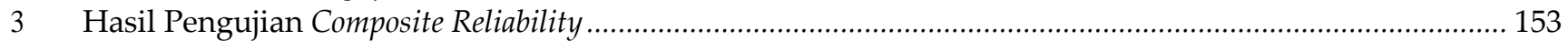

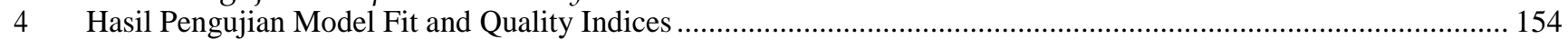

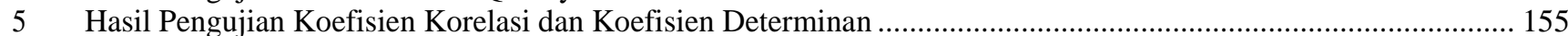

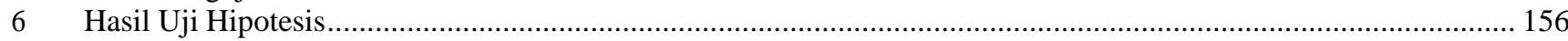


TABEL1/Tingkat Pengembalian Kuesioner Responden Berdasarkan Usia Responden Berdasarkan Tingkat Pendidikan, Agama dan Mengikuti Tax Amnesty

\begin{tabular}{c|c|c|c}
\hline \multirow{2}{*}{ No. } & Keterangan & Jumlah & $\%$ \\
\hline 1 & Kuesioner yang disebarkan & 400 & $100 \%$ \\
\hline 2 & Kuesioner tidak kembali & $(190)$ & $(47 \%)$ \\
\hline 3 & Kuesioner yang dapat diolah & 210 & $53 \%$ \\
\hline
\end{tabular}

\begin{tabular}{|c|c|c|c|}
\hline No. & Usia & \multicolumn{2}{|c|}{ Jumlah } \\
\hline 1 & $<25$ thn & 36 orang & $18 \%$ \\
\hline 2 & $26-35$ thn & 67 orang & $32 \%$ \\
\hline 3 & $36-50$ thn & 85 orang & $40 \%$ \\
\hline 4 & $>50$ thn & 22 orang & $10 \%$ \\
\hline & Jumlah & 210 orang & $100 \%$ \\
\hline
\end{tabular}

\begin{tabular}{c|l|c|c}
\hline \multirow{2}{*}{ No. } & \multicolumn{1}{|c|}{ Tingkat Pendidikan } & \multicolumn{2}{c}{ Jumlah } \\
\hline 1 & SD & 2 orang & $1 \%$ \\
\hline 2 & SMP & 1 orang & $0,5 \%$ \\
\hline 3 & SMU & 57 orang & $27 \%$ \\
\hline 4 & D1 & 4 orang & $2 \%$ \\
\hline 5 & D3 & 24 orang & $11,5 \%$ \\
\hline 6 & S1 & 108 orang & $51,5 \%$ \\
\hline 7 & S2 & 10 orang & $5 \%$ \\
\hline 8 & S3 Jumlah & 2 orang & $1 \%$ \\
\hline \multicolumn{1}{|c|}{ 210 orang } & $\mathbf{1 0 0 \%}$ \\
\hline
\end{tabular}

\begin{tabular}{c|l|c|c}
\hline \multirow{2}{*}{ No. } & \multicolumn{1}{|c|}{ Agama } & \multicolumn{2}{c}{ Jumlah } \\
\hline 1 & Islam & 178 orang & $84 \%$ \\
\hline 2 & Kristen Protestan & 18 orang & $8,5 \%$ \\
\hline 3 & Katholik & 9 orang & $4,3 \%$ \\
\hline 4 & Hindu & 2 orang & $0,9 \%$ \\
\hline 5 & Budha & 1 orang & $0,5 \%$ \\
\hline 6 & Konghucu & 2 orang & $0,9 \%$ \\
\hline \multicolumn{2}{|c|}{ Jumlah } & $\mathbf{2 1 0}$ orang & $\mathbf{1 0 0 \%}$ \\
\hline
\end{tabular}

\begin{tabular}{c|l|c|c}
\hline \multirow{2}{*}{ No. } & \multicolumn{1}{|c|}{ Tax Amnesty } & \multicolumn{2}{c}{ Jumlah } \\
& \multicolumn{2}{|c|}{ 47 orang } & $22,4 \%$ \\
\hline 1 & lkut & 163 orang & $77,6 \%$ \\
\hline 2 & Tidak lkut & $\mathbf{2 1 0}$ orang & $\mathbf{1 0 0 \%}$ \\
\hline \multicolumn{2}{|c|}{ Jumlah }
\end{tabular}


TABEL 2 / Hasil Pengujian Validitas Diskriminan

\begin{tabular}{|c|c|c|c|c|c|c|c|}
\hline Variabel & $\mathbf{X}_{1}$ & $\mathbf{X}_{2}$ & $\mathbf{X}_{3}$ & $\mathbf{X}_{4}$ & $\mathbf{Z}$ & $\mathbf{Y}$ & Hasil \\
\hline Kesadaran Pajak $\left(\mathrm{X}_{1}\right)$ & 1.0000 & 0.692 & 0.723 & 0.757 & 0.721 & 0.720 & Valid \\
\hline Kebijakan Pemerintah $\left(\mathrm{X}_{2}\right)$ & 0.692 & 1.0000 & 0.806 & 0.804 & 0.778 & 0.530 & Valid \\
\hline Citra Otoritas Pajak $\left(\mathrm{X}_{3}\right)$ & 0.723 & 0.806 & 1.0000 & 0.877 & 0.779 & 0.584 & Valid \\
\hline Pemeriksaan Pajak $\left(X_{4}\right)$ & 0.757 & 0.804 & 0.877 & 1.0000 & 0.780 & 0.617 & Valid \\
\hline Religiusitas (Z) & 0.721 & 0.778 & 0.779 & 0.780 & 1.0000 & 0.540 & Valid \\
\hline Kepatuhan Pajak (Y) & 0.720 & 0.530 & 0.584 & 0.617 & 0.540 & 1.0000 & Valid \\
\hline
\end{tabular}

Sumber : Output WarpPLS yang telah diolah (2021) 
TABEL 3 / Hasil Pengujian Composite Reliability

\begin{tabular}{c|l|c|c|c}
\hline No & \multicolumn{1}{|c|}{ Variabel } & $\begin{array}{c}\text { Composite Reliability } \\
\text { Coefficient }\end{array}$ & $\begin{array}{c}\text { Cronbach's Alpha } \\
\text { Coefficient }\end{array}$ & $\begin{array}{c}\text { Hasil } \\
\text { Reliabel }\end{array}$ \\
\hline 1. & Kesadaran Pajak $\left(\mathrm{X}_{1}\right)$ & 0.957 & 0.947 \\
\hline 2. & Kebijakan Pemerintah $\left(\mathrm{X}_{2}\right)$ & 0.957 & 0.941 \\
\hline 3. & Citra Otoritas Pajak $\left(\mathrm{X}_{3}\right)$ & 0.964 & 0.950 \\
\hline 4. & Pemeriksaan Pajak $\left(\mathrm{X}_{4}\right)$ & 0.958 & 0.947 \\
\hline 5. & Kepatuhan Pajak $(\mathrm{Y})$ & 0.940 & 0.920 \\
\hline 6. & Regiulitas $(\mathrm{Z})$ & 0.955 & Reliabel & Reliabel \\
\hline
\end{tabular}


TABEL 4 / Hasil Pengujian Model Fit and Quality Indices

\begin{tabular}{|c|c|c|c|c|}
\hline No & Model fit and quality indices & Kriteria Fit & Hasil Analisis & Keterangan \\
\hline 1 & Average path coefficient (APC) & $\mathrm{P}<0.05$ & $\begin{array}{c}0.165 \\
(p=0.004)\end{array}$ & Baik \\
\hline 2 & Average R-squared (ARS) & $\mathrm{P}<0.05$ & $\begin{array}{c}0.483 \\
(p<0.001)\end{array}$ & Baik \\
\hline 3 & $\begin{array}{l}\text { Average adjusted R-squared } \\
\text { (AARS) }\end{array}$ & $\mathrm{P}<0.05$ & $\begin{array}{c}0.462 \\
(p<0.001)\end{array}$ & Baik \\
\hline 4 & Average block VIF (AVIF) & $\begin{array}{l}\text { Acceptable if }<=5, \text { ideally } \\
<=3.3\end{array}$ & 6.437 & Tidak Ideal \\
\hline 5 & $\begin{array}{l}\text { Average full colliearity VIF } \\
\text { (AFVIF) }\end{array}$ & $\begin{array}{l}\text { Acceptable if }<=5 \text {, ideally } \\
<=3.3\end{array}$ & 6.461 & Tidak Ideal \\
\hline 6 & Tenenhaus GoF (GoF) & $\begin{array}{l}\text { Small }>=0.1, \\
\text { Medium }>=0.25, \\
\text { Large }>=0.36\end{array}$ & 0.648 & Ideal \\
\hline 7 & Sympson's paradox ratio (SPR) & $\begin{array}{l}\text { Acceptable if }>=0.7, \text { ideally } \\
=1\end{array}$ & 0.625 & Tidak Ideal \\
\hline 8 & $\begin{array}{l}\text { R-squared contribution ratio } \\
\text { (SSR) }\end{array}$ & $\begin{array}{l}\text { Acceptable if }>=0.9, \text { ideally } \\
=1\end{array}$ & 0.818 & Tidak Ideal \\
\hline 9 & $\begin{array}{l}\text { Statistical suppresion ratio } \\
\text { (SSR) }\end{array}$ & Acceptable if $>=0.7$ & 1.000 & Ideal \\
\hline 10 & $\begin{array}{l}\text { Nonlinear bivariate causality } \\
\text { direction ratio (NLBCDR) }\end{array}$ & Acceptable if $>=0.7$ & 0.875 & Ideal \\
\hline
\end{tabular}


TABEL 5 / Hasil Pengujian Koefisien Korelasi dan Koefisien Determinan

R-squared coefficients

\begin{tabular}{|r|l|l|l|l|l|l|l|l|l|}
\hline PP_Y & SP_X1 & KP_X2 & COP_X3 & PM_X4 & R_Z & $R_{-} Z^{*} S P_{-}$ & $R_{2} Z^{*} K_{-}$ & $R_{-} Z^{*} C O P$ & $R_{2} Z^{*} P M_{-}$ \\
\hline 0.483 & & & & & & & & & \\
\hline
\end{tabular}

Adjusted R-squared coefficients

\begin{tabular}{|c|l|l|l|l|l|l|l|l|l|}
\hline PP_Y & SP_X1 & KP_X2 & COP_X3 & PM_X4 & R_Z & R_Z*SP_ & R_Z*KP_ & R_Z*COP & R_Z*PM_ \\
\hline 0.462 & & & & & & & & & \\
\hline
\end{tabular}

Sumber: Data diolah dengan WarpPLS 
TABEL 6 / Hasil Uji Hipotesis

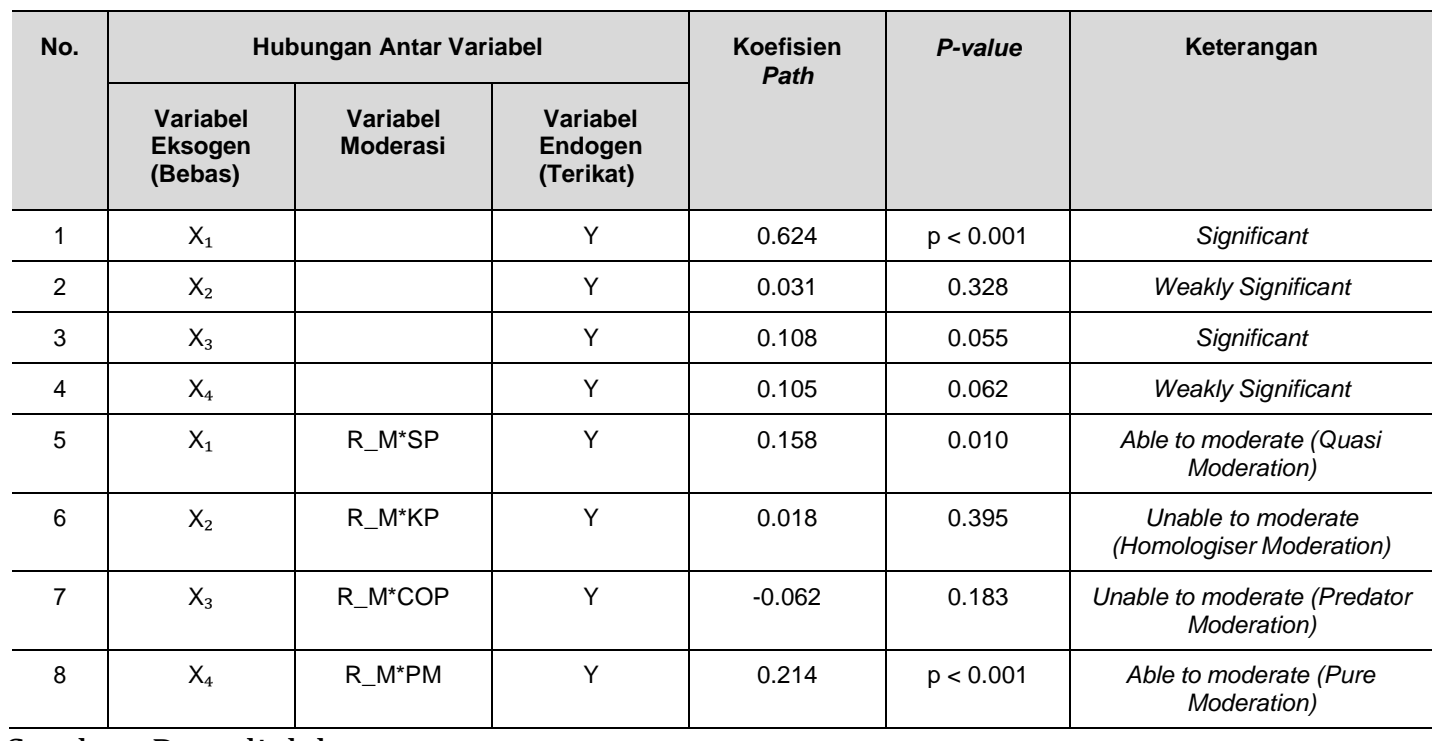

Sumber: Data diolah 


\section{LIST OF FIGURES}

1 Model Stuktur Pengujian Hipotesis

158 
Gambar 1 / Model Stuktur Pengujian Hipotesis

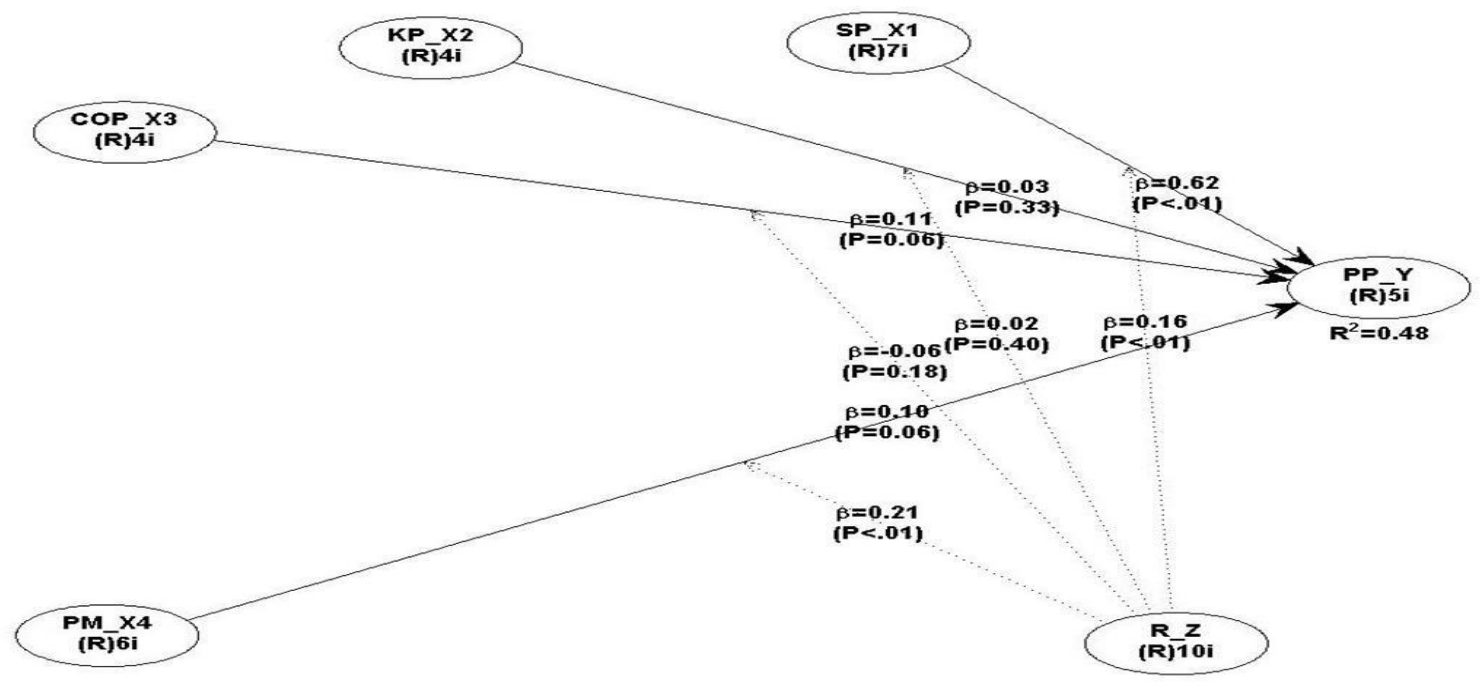

Sumber: Hasil output pengolahan data 